\title{
THE POSITIVE LABOUR PRODUCTIVITY EXTERNALITIES THAT ARISE FROM A POST-SECONDARY PUALIFICATION OR TRAINING
}

\author{
Hardus van Zyl* \\ University of Johannesburg \\ hardusvz@uj.ac.za
}

Received: May 2013

Accepted: July 2013

\begin{abstract}
The aim of this article is to estimate, compute and determine the magnitude of positive labour productivity externalities (defined as unintentional positive labour productivity spill-over effects) generated by employees with a post-secondary education or training (post-grade 12). The research is deemed necessary given the important debate on the shortage of higher-skilled employees and the impact of this on the creation of positive labour productivity spill-over effects in the workplace. Logarithm wage equations for different skill levels and for different geographical areas are derived and estimated in order to determine the existence and magnitude of positive labour productivity externalities created by employees with a post-secondary qualification or training. Higher-skilled employees who have a post-secondary qualification or training and who are employed in a geographical area in which post-secondary education or training institutions are denser tend to create significant positive productivity externalities in the workplace.
\end{abstract}

Keywords

Productivity spill-over effects, logarithm wage equations, skill levels, estimation model, labour productivity externalities

*Prof Hardus van Zyl is professor in Economics in the Department of Economics \& Econometrics, University of Johannesburg, South Africa. 


\section{INTRODUCTION}

The aim of this article is to estimate, compute and determine the magnitude of labour productivity externalities (defined as unintentional positive labour productivity spill-over effects) generated by employees with a post-secondary education or training (post-grade 12) in both the higher-skilled employee and the lower-skilled employee categories.

The general debate on the shortage of skilled labour in the South African workplace and the impact of this on labour productivity is very important. This particular research intends to add new insight into the measurement, quantification and explanation of the possible existence of positive labour productivity spill-over effects due to higher levels of educated or trained employees in the South African workplace. The general assumption is that educated or trained employees create positive labour productivity spill-over effects in the workplace. The quantification of these labour productivity spill-over effects can be a difficult task, and in this regard a unique econometric estimation procedure is presented in which the existence and magnitude of positive labour productivity externalities are estimated, quantified and interpreted. The South African manufacturing sector is used as a case study, and in order to accommodate possible geographical effects it is deemed necessary to compare the estimation results of a geographical area with a higher density of post-secondary education or training institutions (Gauteng Province) with a geographical area that is characterised by a lower density of post-secondary education or training institutions (Mpumalanga Province).

The existence, dynamics and the quantification of labour productivity externalities have been widely researched in developed economies (Naish, 1989; Acemogly \& Angrist, 2000; Moretti, 2004; Ciccone \& Peri, 2006; Dalmazzo \& Blasio, 2007; Fu, 2007; Muravyev, 2008; Rosenthal \& Strange, 2008; Winters, 2008; Navan, 2009; Bratti \& Leombruni, 2009; Martins \& Jin, 2010). Little real research has been published specifically on the measurement of the labour productivity externalities in the South African workplace induced by post-secondary education or training.

By far the majority of the empirical research findings indicate that there is a positive relationship between labour productivity externalities and higher levels of employees with a post-secondary qualification or training (Fu, 2007; Muravyev, 2008; Rosenthal et al. 2008; Bratti et al. 2009). There are research findings, however, that do not indicate labour productivity spillover effects. In this regard the study by Ciccone et al. (2006) indicates that the possible existence of productivity externalities in the United States manufacturing sector is inconclusive. International empirical research findings on education- or training-induced labour productivity externalities indicate that i) geographical differences (Winters, 2008; Martins et al. 2010), ii) different skill levels (Battu, Belfield \& Sloan, 2003; Navan, 2009) and iii) all firm-based and external variables that might potentially impact on the measurement of labour productivity externalities (Naish, 1989; Bratti et al. 2009; Iranzo et al. 2009) must be taken into consideration when labour productivity externalities are estimated, quantified and explained. Rosenthal et al. (2008) and Martins et al. (2010) indicate that firms located in geographical areas that are characterised by a higher density of post-secondary education or training institutions tend to i) attract higher levels of employees with a post-secondary education or training qualification and ii) pay a higher average real wage. The result is the generation of higher levels of positive labour productivity externalities than those firms situated in a geographical area with a lower density of post-secondary education or training institutions. The empirical research findings of Battu et al. (2003), Fu (2007) and Bratti et al. (2009) indicate that $\mathrm{i}$ ) positive productivity externalities are more prominent in the higher-skilled employee 
segment, ii) the positive relationship between labour productivity externalities and real wages is stronger in the higher-skilled employee segment and iii) positive labour productivity externalities are stronger for firms where knowledge and innovations are external to the firm. Acemogly (2000) emphasised the importance of skill-biased technological change as a contributing factor to positive labour productivity externalities. The argument is that an increase in research and development investment within firms necessitates the introduction of labour skill complementary technologies with a resultant increase in the productivity levels of employees with a tertiary education or training (it simply means that the introduction of better technologies requires the upgrading of labour skills). Moretti (2004) and Rosenthal et al. (2008) are of the opinion that positive labour productivity externalities should capture learning-bydoing rather than pecuniary spill-over effects. Learning-by-doing spill-over effects would emerge from the sharing of work-related knowledge between employees with a post-secondary qualification or training and other employees in the workplace. In spatial terms the idea is that work-related knowledge is more likely to be exchanged between employees where job tasks are similar (Moretti, 2004).

Differences in the magnitude and the sign (positive or negative) of productivity externalities in the literature can be attributed to the different kinds of measuring instruments and the specification of the data that was used. In this regard, i) the proxy of employee categories, ii) spatial consideration of the sample group of firms and iii) the usage of either instrumental variable techniques (Duranton, 2006) or ordinary least square models (Dalmazzo et al. 2007; Bratti et al. 2009) are identified as factors contributing towards these discrepancies. A further contributing factor to these discrepancies is the possible existence of endogeneity (Moretti, 2004). Endogeneity in this sense is the correlation between firm-level or geographical unobservable characteristics and firm-based human capital. For example, positive labour productivity externalities might be due to positive external demand shocks to specific firms or sectors with a resultant increase in the employment of educated or trained skilled workers. It is also important to note that the Bratti et al. (2009) study clearly indicates that factors such as the unemployment rate and the proximity of post-secondary education or training institutions must be considered. Their empirical research results indicate negative labour productivity externalities when the unemployment rate is high and positive productivity spill-over effects if the proximity of post-secondary education or training institutions is high.

In order to accommodate the abovementioned, an adapted version of the Bratti et al. (2009) estimation model is used. The validity and the reliability of the Bratti et al. (2009) model have been established in an extensive study on the existence and magnitude of positive labour productivity externalities in the Italian manufacturing industry. This specific model caters for average wage levels, different skill categories, technological indicators, research and development investments, spatial aspects, geographical differences and the existence of either firm or geographical unobservables. The assumption underpinning the model is that higher remuneration levels, ceteris paribus, are associated with higher skill levels and thus higher average productivity levels. This is especially true in the case of geographic regions that are characterised by a greater density of post-secondary education or training institutions. The model is also constructed in such a way that it addresses the possible problems of the endogeneity of firm-based human capital. 


\section{RESEARCH DESIGN}

\subsection{Research approach and method}

The research design comprises the

- specification of an estimation model that would capture the relative labour productivity externalities created in the workplace by employees with a post-secondary education/training (for the different employee categories),

- identification of an industry and geographical areas that would serve as proxies for the estimation and computation of the relative labour productivity externalities,

- statistical validation of the required sample of firms and the data collected in the proxy industry and geographical areas,

- estimation and computation process and

- the interpretation of the estimation and computation results.

\subsection{Model specification}

The methodology of the model of Bratti et al. (2009:7-9), as it is applied in this particular study, is explained in the following few paragraphs. The International Standard Classification of Occupations (ISCO-08) was used for the differentiation of the different skill levels (ILO, 2004). For the purpose of this research category A constitutes the more skilled employee segment (chief executives, senior officials, administrative and commercial managers, production and specialised services managers, sciences and engineering professionals, information and communications technology professionals, process control technicians, administrative and specialised secretaries) while category B constitutes the less skilled employee segment (general office clerks, material-recording and transport clerks, clerical support workers, protective services workers, metal, machinery and related trades workers, handicraft workers, electrical and electronic trades workers, wood treaters, cabinet-makers, stationary plant and machine operators, assemblers, drivers and mobile plant operators, manufacturing labourers). A logarithm wage ordinary least squared regression was done for each skill level (categories A and $B$ ). These equations (in logarithm format) are augmented with different variables that could impact on labour productivity externalities.

Category A:

$$
W_{i p a}=a_{o}+a_{1} k_{1}+T_{1} a_{2}+a_{3} F C S_{i}+a_{4} L C S_{p}+X_{i} a_{5}+\mu_{a i}+\mu_{a p}+\epsilon_{a i}
$$

and

Category B:

$$
W_{i p b}=\beta_{o}+\beta_{1} k_{1}+T_{1} \beta_{2}+a_{3} F C S_{i}+\beta_{4} L C S_{p}+X_{i} \beta_{5}+\mu_{\beta i}+\mu_{\beta p}+\epsilon_{\beta i}
$$

where $i=$ firm, $W_{i p}=$ average hourly wage for firm $i$ in province $p, k_{i}=$ natural logarithm for physical capital intensity, $T_{i}^{\prime}=$ vector of technological indicators and research \& development activities, $F C S_{\mathrm{i}}=$ firm $i$ 's human capital proxied by the share of post-secondary educated/trained employees on total employment, $X_{i}=$ vector of other firm-level controls, 
$L C S_{p}=$ provincial measure of human capital, $\mu=$ firm-level or provincial unobservables respectively, $\varepsilon$ = white noise, $\alpha$ and $\beta=$ indicators of labour productivity externalities)

For possible positive labour productivity externalities to exist $\alpha$ and $\beta$ need to be positive. For the category A employee segment a positive $\alpha$ value is expected based on the assumption that employees with a post-secondary education or training would normally be in category $A$ occupations. It is also indicated that a positive $\beta$ value might be the result of supply substitution effects (specifically in the case of the imperfect substitution of employees based on educational or training levels). The argument is that as fewer category B employees are employed, they become relatively scarcer; hence the increase in their remuneration levels. It is indicated in the model that positive and significant $\beta$ values are a clear indication of positive labour productivity externalities in the category B employee segment.

Separate regressions are done for each wage equation per skill category for the applicable industry in the geographical area. In the first regression only the total share of employees with a post-secondary qualification or training is considered. The aim is to determine the existence and magnitude of positive labour productivity externalities for the applicable industry in the geographical area. In the second regression the firm-level post-secondary education or training employee share is added (that is, the share of employees with such an education or training per individual firm). This is a very important regression as it would indicate the magnitude of labour productivity externalities within the skill categories. A positive estimated coefficient is a confirmation of positive labour productivity externalities within a particular firm.

In order to accommodate possible bias effects from other characteristics that might simultaneously affect the sign and the magnitude of the labour productivity externalities, regional fixed effects, the unemployment rate in the geographical area and the approximation of post-secondary education or training institutions are included in the third regression.

In the fourth regression the complementarity between human capital and technology is taken into consideration. A logarithm physical capital intensity variable is included as an additional regressor. Causality in this regard might go into two different directions, namely, i) firms that hire more post-secondary-educated or -trained employees might also invest in more technology or ii) firms investing in greater levels of technology might also require better-educated or trained employees.

In the fifth regression a dummy variable is included in order to cater for the research and development function within firms as well as information communication technological cooperation with post-secondary education or training institutions. The aim is to measure the research and development and information communication technology intensity within the firm and specifically to determine whether these two variables have a strong or weak impact on labour productivity externalities.

In the sixth regression inter-industry employee remuneration differentials are considered. These remuneration differences might be location-based. The argument is that firms that have a greater demand for post-secondary-educated or -trained employees are most likely to operate in a geographical area where this kind of human capital is abundant.

In the seventh regression the position of a firm in the industry (in terms of market power) is taken into consideration. The assumption is that a higher level of market power might allow firms to attract more post-secondary-educated or -trained employees. 
In the last regression the impact of foreign trade and fixed domestic investment flows on labour productivity externalities is taken into consideration. The argument is that higher levels of export activities and fixed domestic investment flows require higher skill levels (hence more post-secondary-educated or -trained employees).

\subsection{Data collection process}

For the purpose of this study any post-grade-12 education/training was included as a proxy for post-secondary education or training.

The manufacturing industries of the Gauteng and Mpumalanga Provinces of South Africa were identified as case studies. The research required a differentiation between a geographical area that would exhibit a high density of post-secondary education or training institutions (Gauteng Province) and a geographical area that would exhibit a lower density of post-secondary education or training institutions (Mpumalanga Province). The data is firm-based, and contact information on firm and tertiary institutions was supplied by the Manufacturing Sector Education and Training Authority (CATHSSETA), the Manufacturing, Engineering and Related Service Education and Training Authority (MERSET), the Department of Labour, the Department of Higher Education and Statistics South Africa (StatsSA). In order to ensure a statistically significant spread of firms (in various sectors of the manufacturing industry) only firms that had more than 70 employees were included in the sample group. Given this constraint and statistical validation requirements, the sample response sizes (122 firms in the manufacturing sector of the Gauteng Province and 58 firms in the manufacturing sector of Mpumalanga) were found to be statistically significant.

The sample period was the calendar years of 2010 to 2011. For each of the individual firms in the sample groups, data had to be collected/constructed on the number of employees per categories A and B, average weekly working hours per employee, the average hourly remuneration levels (monthly employee remuneration levels were transformed to hourly rates), the number of employees with a post-secondary education or training, the value of total physical real capital outlay, the number of employees who are involved with the research and development component of the firm, the level of cooperation between a firm and postsecondary institutions (measured as a monetary value), the approximated market share of a firm, the exposure of a firm to the export market (in monetary terms), the monetary value of fixed domestic investment flows into a firm and the number of post-secondary education or training institutions per province. The summary sample statistics are presented Annexure A.

All the mean values of the variables are expressed in natural logarithm format. For both provinces the mean hourly employee remuneration level values are higher for category $A$ employees than for category B employees. The mean values are higher for the manufacturing industry in Gauteng Province than for Mpumalanga Province.

The mean values of the share of employees with a post-secondary education or training in terms of the different skill levels clearly indicates a greater share for category A employees than for category B employees. This is the case for both provinces. In terms of the province-based share of employees (with a post-secondary education or training) with the total population (people with a post-secondary education or training), Gauteng Province has the greater mean values for both employee categories. As regards the firm-based share of employees with a post-secondary education or training per skill category, category $A$ employees have a higher mean value than category B employees. 
The mean values of capital intensity (physical real capital outlay per employee), is greater in the manufacturing sector of Gauteng Province compared to the manufacturing sector of Mpumalanga Province.

The mean values of the dummy variables for research and development and information technology cooperation with post-secondary institutions are relatively higher for Gauteng Province (both category A and B employees) than for Mpumalanga Province. The research and development intensity (which measures the ratio of research and development employees and the total number of employees) produced higher mean values for category A employees in both provinces.

\section{THE ESTIMATION RESULTS}

The parameter estimates of the non-linear employee remuneration equations per employee category and per province are listed in TABLES 1 and 2. Only the results of the final estimations are presented. The final estimations produce the final labour productivity externality estimates when all the variables are taken into consideration at the same time. TABLE 1 contains the estimates for the category A employee segment of the two provinces.

\section{TABLE 1: Parameter estimates for the wage function of the category A employee segment}

\begin{tabular}{ccc}
\hline Parameter & \multicolumn{2}{c}{ Parameter estimates } \\
& Gauteng & Mpumalanga \\
\hline$\alpha_{1} k_{i}$ & 0.073 & 0.041 \\
& $(0.003)$ & $(0.002)$ \\
$\alpha_{2} T_{i}$ & 0.913 & 0.671 \\
& $(0.002)$ & $(0.0015)$ \\
$\alpha_{3} F C S_{i}$ & 1.414 & 0.802 \\
& $(0.063)$ & $(0.041)$ \\
$\alpha_{4} L C S_{i}$ & 1.041 & 0.475 \\
& $(0.21)$ & $(0.10)$ \\
$\alpha_{5} X_{i}^{\prime}$ & 0.004 & 0.0015 \\
& $(0.001)$ & $(0.0009)$ \\
$\mu \alpha_{p}$ & 0.0015 & 0.0004 \\
& $(0.0008)$ & $(0.0001)$ \\
$\mu \alpha_{i}$ & 0.0022 & 0.0014 \\
& $(0.0005)$ & $(0.0003)$ \\
& -0.003 & 0.0001 \\
& $(0.00012)$ & $(0.00008)$ \\
\hline
\end{tabular}

Source: Author's analysis

*the standard errors are significant at a $10 \%$ confidence level and are in parenthesis 
The estimated parameters for capital intensity, technological indicators, the share of postsecondary educated or trained employees, the density indicator, the firm-level control vector and the firm and provincial level unobservables are all positive but significantly greater for the manufacturing industry of Gauteng Province.

TABLE 2 contains the estimates for the category B employee segment of the two provinces.

TABLE 2: Parameter estimates for the wage function of the category B employee segment

\begin{tabular}{ccc}
\hline Parameter & \multicolumn{2}{c}{ Parameter estimates } \\
& Gauteng & Mpumalanga \\
\cline { 2 - 3 }$\beta_{1} k_{i}$ & 0.004 & 0.003 \\
$\beta_{2} T_{i}$ & $(0.0008)$ & $(0.0006)$ \\
& 0.084 & 0.042 \\
$\beta_{3} F C S_{i}$ & $(0.031)$ & $(0.009)$ \\
& 1.008 & 0.651 \\
$\beta_{4} L C S_{i}$ & $(0.72)$ & $(0.02)$ \\
& 0.833 & 0.514 \\
$\beta_{5} X_{i}^{\prime}$ & $(0.12)$ & $(0.23)$ \\
& 0.0037 & 0.0031 \\
$\mu \beta_{p}$ & $(0.0010)$ & $(0.0012)$ \\
& 0.0014 & 0.0009 \\
$\mu \beta_{i}$ & $(0.0006)$ & $(0.0003)$ \\
& 0.0014 & 0.0010 \\
$\varepsilon \beta_{i}$ & $(0.0006)$ & $(0.0004)$ \\
& -0.00015 & -0.00012 \\
\hline
\end{tabular}

Source: Author's analysis

*the standard errors are significant at a $10 \%$ confidence level and are in parenthesis

The estimated parameters for capital intensity, technological indicators, the share of postsecondary-educated or -trained employees, the density indicator, the firm-level control vector and the firm and provincial level unobservables are all positive, but they are again significantly greater for the manufacturing industry of Gauteng Province. It is important to note that the estimated coefficients of the category $A$ employee segment are greater than those of the category B employee segment.

The estimation results of both category A and B employee segments in the two geographical areas (Gauteng and Mpumalanga) are interpreted in the following manner:

- The positive estimates for the capital intensity coefficient $\left(\alpha_{1} k_{i}\right.$ and $\left.\beta_{1} k_{i}\right)$, for both employee categories in both provinces indicate that a higher level of investment in capital 
stock (technology) requires a higher level of skilled employees (employees with a postsecondary education or training). The relationship between technology and skilled employees is complementary, and it creates positive labour productivity externalities in the workplace. The magnitude of these positive labour productivity externalities is greater for the category A employee segment (compared to the category B employee segment) and also greater in the geographical area (Gauteng) that is characterised by a higher density of employees with a post-secondary education or training

- The positivity and the magnitude of the research and development indicator vector $\left(\alpha_{2} T_{i}\right.$ and $\beta_{2} T_{i}$ ) estimates in both employee categories indicate the strong positive impact that research and development inputs have on the creation of positive labour productivity externalities. Research and development within a firm is thus a strong channel through which positive labour productivity externalities are transmitted. The magnitude thereof is less for the category B employee segment and also smaller for the geographical area (Mpumalanga) that is characterised by a lower density of employees with a post-secondary education or training.

- The positive estimates for the firm-based share of employees with a post-secondary education or training $\left(\alpha_{3} F C S_{i}\right.$ and $\left.\beta_{3} F C S_{i}\right)$ indicate that higher levels of employees with a post-secondary education or training within a firm create a greater magnitude of positive labour productivity externalities. It is more so for the category A employee segment and also if the firm is situated in a geographical area that has a greater density of such employees (Gauteng).

- The magnitude and positivity of the provincial-based share of employees $\left(\alpha_{4} L C S_{i}\right.$ and $\beta_{4} L C S_{i}$ ) with a post-secondary education or training are in support of the creation of stronger positive labour productivity externalities in the workplace if the firm is located in a geographical area that is characterised by a higher density of post-secondary education or training institutions (Gauteng). It is also stronger in the case of the category A employee segment.

- The magnitude of the positive impact on labour productivity externalities is very small when firm-level controls $\left(\alpha_{5} X_{i}^{\prime}\right.$ and $\left.\beta_{5} X_{i}^{\prime}\right)$ such as the market power of a firm and the level of exposure to export markets are considered. It is very small for category $B$ employees and for a firm situated in a geographical area that is characterised by a low density of postsecondary education or training institutions (Mpumalanga).

- The positive provincial-level and firm-level $\left(\mu_{\alpha p}\right.$ and $\left.\beta \mu_{\alpha i}\right)$ unobservable estimates are very small, thus indicating very limited impact on the creation of positive labour productivity externalities. This is especially true for category B employees and for a firm situated in a geographical area that is characterised by a lower density of post-secondary education or training institutions.

The results of this study support i) the research findings of the Winters (2008) and Martins et al. (2010) studies, which clearly indicate that geographical differences do create a different magnitude of positive labour productivity externalities, ii) the conclusion of the Battu et al. (2003), Fu (2007), Bratti et al. (2009) and Navon (2009) studies, which indicate that employees with higher skill levels (post-secondary education or training) do create higher levels of positive labour productivity externalities and iii) the Acemagly (1998) research findings, which clearly indicated that technology and research and development activities serve as important transmitters of positive labour productivity externalities within firms. 


\section{SUMMARY AND CONCLUSION}

The aim of the article was to estimate, compute, quantify and interpret the magnitude of labour productivity externalities in the workplace generated by employees with a post-secondary education or training.

The results of this particular study are, again, a confirmation of the need for a constant improvement in the skill levels of employees if general labour productivity levels are to increase. In this regard the findings of the study serve as a confirmation of the importance of the employees with post-secondary education or training qualifications. These employees are mainly responsible for the creation of research and development activities, the implementation of new technologies and the creation of learning-by-doing effects in the workplace. Effective strategies aimed at the constant upgrading of education or training possibilities for employees are of the utmost importance. In a broader sense the results of this study should also serve as a reminder to policy-makers that more and better-focused quality post-secondary education or training institutions are a necessity in all geographical areas if higher labour productivity levels are to be created throughout the economy.

Further possible extensions of this particular study are possible, including i) industry differences and ii) gender differences on labour productivity externalities.

\section{LIST OF REFERENCES}

Acemoglu, D. \& Angrist, J. (2000). How large are human capital externalities? Evidence from compulsory schooling laws. NBER Macroeconomic Annual, 15(1), pp. 9-59.

Battu, H., Belfield, C.R., \& Sloane, P.J. (2003). Human capital spill-overs within the workplace: Evidence for Great Britain. Oxford Bulletin of Economics \& Statistics, 65(5), pp. 575-594.

Bratti, M. \& Leombruni, R. (2009). Local human capital externalities and wages at the firm level. IZA (Discussion Paper Series, (4613), pp. 1-39)

Ciccone, A. \& Peri, G. (2006). Identifying human capital externalities: Theory with applications. Review of Economic Studies, 73(2), pp. 381-412

Dalmazzo, A. \& De Blasio, G. (2007). Production and consumption externalities of human capital: An empirical study for Italy. Journal of Population Economics, 20(2), pp. 359-382.

Duranton, G. (2006). Human capital externalities in cities: Identification and policy issues. In Arnott, R., \& McMillen, D. (Eds), A Companion to Urban Economics, Blackwell Publishing Ltd., Oxford.

Fu, S. (2007). Smart café cities: Testing human capital externalities in the Boston metropolitan area. Journal of Urban Economics, 61 (1), pp. 86-111.

International Labour Organisation (ILO). (2004). The international classification of occupations.

[Online] Available: http://www.ilo.org/public/english/bureau/stat/isco/isco08/index.htm.

(Accessed 30 November 2011)

Iranzo, S. \& Peri, G. (2009). Schooling externalities, technology and productivity: Theory ans evidence from the United States. Review of Economics and Statistics, 91(2), pp. 420-431.

Martins, P.S. \& Jin, J.Y. (2010). Firm level social returns to education. IDEAS, 23(2), pp. 539-558. 
THE POSITIVE LABOUR PRODUCTIVITY EXTERNALITIES THAT ARISE FROM A POST-SECONDARY PUALIFICATION ...

Moretti, દ. (2004). Estimating the social return to higher education: Evidence from longitudinal and repeated cross-sectional data. Journal of Econometrics, 121 (2), pp. 175-212.

Naish, H.F. (1989). Labor market externalities and the downward inflexibility of nominal wages.

Journal of Post Keynesian Economics, 12(1), pp. 109-126.

Navon, G. (2009). Human capital spill-overs in the workplace: Labor diversity and productivity, MPRA paperseries, (17741), pp. 1-32.

Muravyev, A. (2008). Human capital externalities: Evidence from the transition economy of Russia. Economics of Transition, 16(3), pp. 415-443.

Rosenthal, S.S. \& Strange, W.C. (2008). The attenuation of human capital spill-overs. Journal of Urban Economics, 64(2), pp. 373-389.

Winters, J.V. (2008). Human capital externalities and employment differences across Metropolitan areas of the United States. (IZA Discussion Paper Series, (6869), pp. 1-344) 


\section{ANNEXURE A: Summary of the sample statistics}

\begin{tabular}{|c|c|c|c|c|}
\hline \multirow[t]{2}{*}{ Variables } & \multicolumn{2}{|c|}{ Gauteng } & \multicolumn{2}{|c|}{ Mpumalanga } \\
\hline & Category $A$ & Category B & Category $A$ & Category $B$ \\
\hline \multirow[t]{2}{*}{ Ln average hourly remuneration } & 62.17 & 39.21 & 57.04 & -2.79 \\
\hline & $(0.37)$ & $(0.15)$ & $(0.44)$ & $(0.19)$ \\
\hline \multirow{2}{*}{$\begin{array}{l}\text { Ln Industry-based post -grade } \\
12 \text { education/training share }\end{array}$} & 0.07 & 0.02 & 0.03 & 0.01 \\
\hline & $(0.01)$ & $(0.009)$ & $(0.008)$ & $(0.005)$ \\
\hline \multirow{2}{*}{$\begin{array}{l}\text { Ln Provincial-based post-grade } \\
12 \text { education/training share }\end{array}$} & 0.32 & 0.19 & 0.14 & 0.08 \\
\hline & $(0.05)$ & $(0.06)$ & $(0.03)$ & $(0.02)$ \\
\hline \multirow{2}{*}{$\begin{array}{l}\text { Ln Firm-based post -grade } 12 \\
\text { education/training share }\end{array}$} & 0.63 & 0.27 & 0.41 & 0.21 \\
\hline & $(0.01)$ & $(0.04)$ & $(0.02)$ & $(0.08)$ \\
\hline \multirow[t]{2}{*}{ Ln capital intensity } & 2.71 & 2.13 & 1.63 & 1.57 \\
\hline & $(1.81)$ & $(1.61)$ & $(0.88)$ & $(0.71)$ \\
\hline \multirow{2}{*}{$\begin{array}{l}\text { Ln research \& development and } \\
\text { communication technology } \\
\text { cooperation with tertiary } \\
\text { institutions }\end{array}$} & 0.07 & 0.04 & 0.02 & 0.01 \\
\hline & $(0.0008)$ & $(0.01)$ & $(0.001)$ & $(0.004)$ \\
\hline \multirow{2}{*}{$\begin{array}{l}\text { Ln firm-based research \& } \\
\text { development intensity }\end{array}$} & 0.09 & 0.02 & 0.04 & 0.001 \\
\hline & $(0.02)$ & $(0.007)$ & $(0.01)$ & $(0.002)$ \\
\hline \multirow[t]{2}{*}{ Ln size of firms } & 0.87 & 1.07 & 0.66 & 1.03 \\
\hline & $(0.17)$ & $(0.24)$ & $(0.21)$ & $(0.31)$ \\
\hline \multirow{2}{*}{$\begin{array}{l}\text { Ln dummy variable for export } \\
\text { trade }\end{array}$} & 0.67 & 3.30 & 0.67 & 3.12 \\
\hline & & (1.23) & & $(1.01)$ \\
\hline \multirow{2}{*}{$\begin{array}{l}\text { Ln dummy variable for foreign } \\
\text { direct investment }\end{array}$} & 0.32 & 1.04 & 0.31 & 0.98 \\
\hline & & $(0.77)$ & & $(0.56)$ \\
\hline
\end{tabular}

Source: Author's analysis

*the standard errors are significant at a $10 \%$ confidence level and are in parenthesis 